\title{
MOTIVASI KEMBALI DAN PEMANFAATAN REMITAN BURUH MIGRAN DI DESA SENYIUR KECAMATAN KERUAK
}

\author{
Abdul Rasyid ${ }^{1}$, Suroso ${ }^{2 *}$, Sri Agustina \\ Program Studi Pendidikan Geografi, Fakultas Ilmu Sosial dan Ekonomi, Universitas Hamzanwadi, Selong, Indonesia \\ *Email Koresponden: 59roso@gmail.com \\ Diterima: 23-06-2020, Revisi: 24-06-2020, Disetujui: 28-06-2020 \\ C)2020 Program Studi Pendidikan Geografi, FISE, Universitas Hamzanwadi
}

\begin{abstract}
Abstrak Penelitian ini bertujuan untuk mengetahui: 1) tingkat motivasi kembali bagi buruh migran ke luar negeri untuk bekerja; 2) jenis dan tingkat pemanfaatan remitan buruh migran di Desa Senyiur Kecamatan Keruak. Metode yang digunakan adalah penelitian survey dengan pendekatan deskriptif. Pengumpulan data dilakukan dengan angket, wawancara, observasi dan dokumentasi. Dalam penelitian ini ditetapkan 42 orang sebagai sampel dengan teknik snowball sampling. Subyek dalam penelitian ini adalah masyarakat Desa Senyiur yang memiliki satu atau lebih anggota keluarga menjadi buruh migran, dan telah melakukan migrasi kembali di atas tiga kali. Sedangkan teknik analisis data yang digunakan adalah analisis deskiriptif persentase. Hasil penelitian menunjukkan bahwa: 1) motivasi buruh migran untuk kembali bekerja ke luar negeri berada pada kategori tinggi dengan persentase $78,16 \%$; 2) pemanfaatan remitan untuk kegiatan konsumtif berada pada kategori tinggi dengan persentase $89,40 \%$. Sementara pemanfaatan untuk kegiatan ekonomi produktif berada pada kategori rendah dengan persentase $10,6 \%$.
\end{abstract}

Kata kunci: motivasi kembali, buruh migran, pemanfaatan remitan

\begin{abstract}
This study aims to determine: 1) the level of motivation for returning migrant workers to work abroad; 2) type and level of remittance utilization of migrant workers in the Senyiur Village, Keruak. District. The method used is survey research with a descriptive approach. Data collection is done by questionnaire, interview, observation and documentation. In this study, 42 people were selected as samples with the snowball sampling technique. The subjects in this study were the people of Senyiur Village who had one or more family members to become migrant workers, and had migrated again over three times. While the data analysis technique used is percentage descriptive analysis. The results showed that: 1) the motivation of migrant workers to return work to abroad was in the high category with a percentage of $78.16 \%$; 2) utilization of remittances for consumptive activities is in the high category with a percentage of $89.40 \%$. While the utilization for productive economic activities is in the low category with a percentage of $10.6 \%$.
\end{abstract}

Keywords: returning motivation, migrant workers, utilization of remittances

\section{PENDAHULUAN}

Migrasi tenaga kerja merupakan fenomena global yang terjadi pada sebagian besar negara di dunia. Fenomena ini terus berkembang seiring dengan dinamika hubungan yang terjalin antar negara. Semakin baiknya hubungan antar negara akan mempengaruhi intensitas arus migrasi ke negara bersangkutan. Pergerakkan modal termasuk mobilitas sumberdaya manusia sedemikian menarik sehingga fenomena migrasi tenaga kerja internasional tidak terelakan. Pesatnya pertumbuhan ekonomi di negara-negara Asia Pasifik seperti Singapura, Hongkong, Malaysia, Taiwan, Korea Selatan dibandingkan Kawasan lainnya menyebabkan daya tarik tersendiri dan berpeluang mendatangkan tenaga kerja internasional (Tjiptoherijanto, 1997). Meningkatnya jumlah tenaga kerja migran dari tahun ke tahun untuk bekerja di luar negeri merupakan salah satu indikator dari globalisasi. Indonesia sebagai bagian integral dari ekonomi global tidak dapat melepaskan diri dari dinamika tersebut. Pengiriman pekerja migran ke luar negeri berdampak signifikan pada makro ekonomi.

Pada kenyataannya, kesulitan mencari pekerjaan dengan gaji yang layak memang sudah menjadi permasalahan nasional. Banyaknya pengangguran usia produktif disebabkan karena sempitnya lapangan 
kerja formal. Proses seseorang untuk melakukan migrasi tentunya diawali dengan sebuah motivasi, baik yang berasal dari dalam diri (intrinsik) maupun yang berasal dari luar (ekterinsik). Hal tersebut tentu melalui proses pertimbangan terlebih dahulu, yakni, negara manakah yang akan dituju. Individu dalam suatu masyarakat mempunyai kebutuhan tertentu untuk dapat dipenuhi. Apabila di suatu wilayah kebutuhan tersebut tidak dapat dipenuhi maka akan terjadi tekanan. Intensitas tekanan dari seorang ini tergantung pada besar kecilnya kebutuhan yang dapat dipenuhi di mana mereka berada. Beberapa faktor pendorong lainnya yang menyebabkan penduduk meninggalkan desa antara lain karena penghasilan di desa relatif rendah, pekerjaan di bidang pertanian relatif kurang, dan tidak punya tanah garapan yang memadai (Mantra, 2011).

Salah satu tujuan migrasi tenaga kerja adalah Negara Malaysia. Migrasi tenaga kerja ke Negara Malaysia dengan iming-iming gaji yang tinggi serta kondisi sulitnya kerja di dalam negeri menyebabkan tawaran pekerjaan sebagai buruh migran tak pernah surut peminatnya. Bahkan, sekalipun berbagai kasus penganiayaan terhadap buruh migran kerap terjadi. Sebagian masyarakat tidak setuju jika pengiriman buruh migran dilarang. Penghasilan yang tinggi itulah yang menyebabkan orang rela bersusah payah bekerja di luar negeri. Dinas Tenaga Kerja dan Transmigrasi (Disnakertrans) Nusa Tenggara Barat mencatat sebanyak 56.672 warganya memilih untuk mengadu nasib sebagai buruh migran Indonesia. Dari 56.672 orang tersebut terdiri atas 45.256 orang laki-laki dan 11.416 orang perempuan. Mereka berasal dari Kota Mataram sebanyak 140 orang, Kabupaten Sumbawa sebanyak 3.998 orang, Dompu sebanyak 713 orang, Bima sebanyak 1.709 orang Kabupaten Lombok barat sebanyak 4.602 orang, Lombok Tengah sebanyak 8.239 orang, Lombok Timur sebanyak 24.281 orang, dan Lombok Utara sebanyak 887 orang (antarnews.com: 2015).

Disnakertrans NTB menyatakan bahwa sebagian besar buruh migran Indonesia yang berasal dari provinsi NTB di luar negeri bekerja di sektor informal, seperti di perkebunan, bangunan dan pembantu rumah tangga di negara Malaysia, Brunei Darussalam, Singapura, Taiwan dan Hongkong. Tidak jauh berbeda dengan jenis pekerjaan yang pernah dilakukan di daerah asal mengingat keterbatasan skill atau keahlian dalam bekerja maka para buruh migran mau tidak mau diberikan satu pilihan, yaitu di sektor informal (Suroso, 2017). Selain itu, di sejumlah negara kawasan timur tengah seperti Oman dan Bahrain. Kabupaten Lombok Timur masih menjadi daerah asal pengiriman buruh migran terbesar di NTB yang mencapai 2.401 orang pada tahun 2018. Jumleh tersebut tertinggi jika dibandingkan dengan kabupaten/kota se- Indonesia. Pihak disnakertrans terus berupaya meningkatkan jumlah buruh migran yang di tempatkan di luar negeri bekerja di sektor formal. Upaya meningkatkan kompetensi para calon buruh migran dilakukan melalui Balai Latihan Kerja Internasional (BLKI) yang dibentuk oleh kementrian ketenagakerjaan di Kabupaten Lombok Timur (suarantb.com, 2018).

Desa Senyiur terletak di Kecamatan Keruak Kabupaten Lombok Timur. Desa ini merupakan desa pemekaran baru dari Desa Sepit yang mekar pada tahun 2012. Mayoritas masyarakat yang tinggal di Desa Senyiur bekerja di sektor pertanian dan peternakan. Selain itu, ada pula yang bekerja di sektor perkantoran, pemerintahan, sebagai tenaga pengajar/dosen (baik honorer maupun menjadi pegawai negeri sipil), pedagang-pedagang kecil dan sebagai buruh migran. Rendahnya penghasilan di sektor pertanian, sedikitnya areal yang dimiliki, serta sedikitnya lapangan pekerjaan yang tersedia, menyebabkan sebagian masyarakat Desa Senyiur memillih untuk mencari pekerjaan baru terutama sebagai buruh migran di luar negeri. Tujuannya tentu saja agar dapat memenuhi semua kebutuhan hidup keluarga sehari-hari, maupun biaya hidup di kemudian hari. Selain itu upah yang tinggi di negara tujuan menjadi daya tarik tersendiri. Ketimpangan upah yang sangat mencolok antara daerah asal dan daerah tujuan menjadi penyebab utama besarnya migrasi keluar (Haris, 2005). Dari hasil bekerja di luar negeri, para buruh migran dapat mengirimkannya kepada keluarga masing-masing di daerah asal (Remitan). Remitan yang dikirimkan ke keluarga oleh para buruh migran berkisar antara satu juta lima ratus ribu rupiah sampai delapan juta lima ratus ribu rupiah per-bulannya sesuai dengan jenis pekerjaan dan negara tempat bekerja (BPS, 2018).

Besarnya jumlah penghasilan buruh migran yang dikirimkan pada keluarga di kampung halamannya akan berdampak pada perubahan kondisi keluarga, baik dari segi sosial maupun ekonomi. Sebagian remitan buruh migran yang dikirim untuk pengiriman pertama kalinya, biasanya digunakan untuk membayar hutang yang mereka pergunakan untuk membiayai keberangkatan mereka sebagai 
buruh migran di luar negeri. Sesudah itu baru dipergunakan untuk kebutuhan-kebutuhan lainnya. Pada dasarnya para buruh migran pergi bekerja ke luar negeri dengan harapan agar kondisi sosial dan ekonominya menjadi lebih baik. Namun demikian berdasarkan observasi awal, peneliti menemukan sebuah fenomena yaitu suatu keadaan ketika para migran pulang ke rumah mereka masing-masing dari negara tempat mereka bekerja. Dalam selang waktu satu minggu sampai satu bulan para migran sudah berencana untuk berangkat kembali merantau ke negara tempat mereka bekerja. Salah satu alasan mengapa mereka ingin segera kembali bekerja adalah perbekalan berupa uang yang mereka bawa dari Negara tempat mereka bekerja sudah menipis, sehingga tentu akan kesulitan untuk memenuhi berbagai kebutuhan mereka dan keluarganya.

Muncul sebuah pertanyaan, untuk apa saja remitan yang telah mereka kirim kepada keluarganya. Meskipun bukan hal yang salah jika remitan habis digunakan oleh keluarga migran. Akan tetapi akan lebih bijak jika para buruh migran dan keluarganya memanfaatakan remitan yang dimiliki dengan sebaik-baiknya. Hal ini bertujuan agar mereka tidak selamanya menjadi buruh migran di negara tempat mereka bekerja. Para buruh migran seharusnya menyisihkan sebagian uangnya untuk jaminan hari tua sesuai dengan tujuan remitan itu sendiri (Yulkardi et al., 2000). Sehingga mereka tidak lagi terjebak menjadi buruh migran seumur hidup, namun dapat bekerja kembali dengan lebih layak dan menikmati hidup di kampung halaman masing-masing.

Permasalahan yang terlukiskan pada fenomena yang telah dijelaskan sebelumnya mendorong peneliti untuk melakukan penelitian dan mengetahui lebih jauh bagaimana tingkat motivasi buruh migran dalam memanfaatkan remitan. Apa saja bentuk pemanfaatan remitan tersebut. Apakah hanya digunakan untuk kebutuhan konsumtif atau untuk ekonomi produktif. Dengan mengetahui jawaban dari pertanyaan tersebut tentu dapat dijadikan pijakan dasar dalam menangani persoalan yang menyangkut pengelolaan keuangan bagi para buruh migran. Sehingga permasalahan-permasalahan semacam ini tidak muncul kembali di kemudian hari. Pertanyaan ini menjadi pendorong peneliti untuk mengetahui dengan pasti dan menjadikannya sebagai tujuan dari penelitian ini.

Terdapat beberapa penelitian sebelumnya yang mengkaji tentang pemanfaatan remitan. Irwanty \& Wahyuni (2011) meneliti tentang migrasi internasional perempuan desa dan pemanfaatan remitan di Desa Pusakajaya. Ia menemukan bahwa Pemanfaatan remitan di Desa Pusakajaya dialokasikan untuk memenuhi kebutuhan konsumsi, produksi, investasi di bidang pendidikan dan ekonomi. Subianto (2006) meneliti tentang pemanfaatan remitan kaitannya dengan pertumbuhan ekonomi wilayah, ia menemukan bahwa pemanfaatan remitan dapat mendorong pertumbuhan ekonomi lokal dalam jangka panjang dan berkelanjutan. Pangestu (2015) lebih mengarahkan penelitiannya pada pemanfaatan remitan untuk pendidikan anak, hasilnya menunjukkan remitan migran perempuan mampu mencukupi kebutuhan pendidikan formal anak dan kebutuhan fasilitas pendukung pendidikan anak dengan jumlah besar. Astuti \& Giyarsih (2013) meneliti pemanfaatan remitan terhadap peningkatan kualitas permukiman. Hasil penelitian tersebut menujukkan adanya peningkatan jumlah rumah tangga yang mempunyai kualitas permukiman tinggi yaitu dari 31,94\% sebelum menjadi buruh migran menjadi $55,56 \%$ setelah menjadi buruh migran. Sementara itu, Sriwanto (2019) memfokuskan kajiannya pada pemanfaatan remitan untuk pemberdayaan pertanian. Hasil penelitiannya menunjukkan bahwa remitan yang dikirimkan dimanfaatkan untuk membeli lahan pertanian, selain itu 56,6 persen remitannya digunakan sebagai model bertani. Melihat beragamnya fokus kajian pada penelitian-penelitian sebelumnya, maka pada penelitian ini dalam posisinya sebagai penelitian pendahuluan sangat penting mengetahui gambaran motivasi buruh migran dalam pemanfaatan remitan khususnya untuk tujuan konsumtif atau kebutuhan ekonomi produktif.

\section{METODE PENELITIAN}

Metode yang digunakan adalah penelitian survey dengan pendekatan deskriptif. Metode survei digunakan untuk mengetahui tingkat motivasi buruh migran dalam memanfaatkan remitan. Sehingga dapat diketahui persentase tingkat motivasi buruh migran yang masuk pada kategori tinggi, sedang atau rendah. Sedangkan pendekatan deskriptif digunakan untuk menggambarkan data berdasarkan indikatorindikator penelitian. Penelitian ini dilaksanakan di Desa Senyiur, Kecamatan Keruak, Kabupaten 
Lombok Timur, NTB. Untuk mengetahui tingkat motivasi buruh migran dalam pemanfaatan remitan maka sebagai populasi dalam penelitian ini yaitu seluruh penduduk yang pernah menjadi buruh migran. Sedangkan sampel penelitian ini adalah anggota keluarga buruh migran yang sudah melakukan migrasi kembali di atas tiga kali. Sehingga jumlah sampel yang ditemukan sebanyak 42 orang dengan menggunakan teknik snowball sampling. Teknik pengumpulan data yang digunakan yaitu angket, wawancara, observasi dan dokumentasi. Angket digunakan untuk mengetahui persentase jawaban responden, observasi digunakan untuk mengetahui keadaan pemanfaatan remitan di lapangan, wawancara digunakan memperjelas berbagai informasi terkait indikator-indikator penelitian di lapangan, sedangkan dokumentasi digunakan mendapatkan data-data dokumen yang diperlukan serta dokumentasi berupa gambar terkait pemanfaatan remitan.

Adapun teknik analisis data yang digunakan adalah analisis deskriptif persentase dengan tahapan sebagai berikut:

1) Pemeriksaan data

Pada tahap ini angket diperiksa kembali satu persatu setelah proses pengumpulan data di lapangan selesai. Hal ini dilakukan dengan maksud untuk mengecek, apakah semua angket telah lengkap dari segi jumlah dan telah diisi sesuai petunjuk.

2) Pengelompokan dan pengkodean data

Pemberian kode dilakukan terhadap angket yang memiliki pilihan item jawaban sama pada satu soal.

Hal ini dimaksudkan untuk mempermudah dalam proses tabulasi dan analisis data.

3) Tabulasi data

Tabulasi data adalah proses penyusunan atau penyajian data dalam bentuk tabel distribusi frekuensi. Penyajian data ini dimaksudkan untuk mengetahui persentase (\%) dari frekuensi item jawaban pada angket atau kuisioner yang telah diisi. Adapun untuk mengetahui persentase dari frekuensi item jawaban diperoleh melalui perhitungan dengan rumus persentase berikut:

$$
\begin{aligned}
& \mathrm{P}=\frac{\mathrm{f}}{\mathrm{n}} \times 100 \\
& \text { Keterangan : } \\
& \mathrm{P} \quad=\text { Persentase }(\%) \\
& \mathrm{f} \quad=\text { Frekuensi jawaban responden } \\
& \mathrm{n} \quad=\text { Jumlah responden } \\
& 100 \quad=\text { Bilangan tetap.....................(Hadi, 2016) }
\end{aligned}
$$

4) Analisis data

Pada tahap ini, keseluruhan data yang telah disajikan dalam bentuk tabel distribusi frekuensi dianalisis dengan cara :

a. Menentukan nilai maksimal dan nilai minimal per item soal

b. Melakukan tabulasi data dari keseluruhan tabel distribusi frekuensi

5) Penarikan kesimpulan

Berdasarkan hasil perhitungan analisis akhir maka diperoleh hasil berupa angka prsentase. Dari hasil tersebut kemudian dilihat rentangannya pada tabel kriteria tingkat penerimaan siswa yang telah ditentukan. Adapun cara menentukan tingkat kriteria adalah sebagai berikut:

a. Menentukan angka persentase tertinggi

Skor maksimal x 100\%

Skor maksimal

$\frac{3}{3} \times 100 \%=100 \%$

b. Menentukan angka persentase terendah

Skor minimal x 100\%

Skor minimal 
$\frac{1}{3} \times 100 \%=33,3$ dibulatkan menjadi $33 \%$

c. Membuat tabel kriteria analisis persentase

Tabel 1. Kriteria analisis persentase

\begin{tabular}{|c|c|c|}
\hline No & Persentase & Kriteria \\
\hline 1 & $68-100 \%$ & Tinggi \\
\hline 2 & $34 \%-67 \%$ & Sedang \\
\hline 3 & $1 \%-33 \%$ & Rendah \\
\hline
\end{tabular}

d. Mencocokkan hasil persentase dengan rentang angka persentase pada tabel kriteria kemudian menyimpulkannya

\section{TEMUAN DAN PEMBAHASAN}

\section{Motivasi Buruh Migran Kembali}

Untuk mengetahui tingkat motivasi buruh migran untuk kembali ke negara tempat mereka bekerja maka diperoleh 13 alasan utama. Alasan-alasan tersebut antara lain: 1) Keinginan mencukupi konsumsi (kebutuhan makan) keluarga ; 2) Keinginan membiayai sekolah anak; 3) Keinginan meningkatkan status sosial; 4) Faktor lemahnya ekonomi keluarga; 5) Keinginan mengirim uang kepada keluarga; 6) Keinginan mengirim barang kepada keluarga; 7) Upah rendah di daerah asal; 8) Keinginan menggapai cita-cita; 9) Keinginan membangun rumah pribadi; 10) Keinginan untuk menabung; 11) Keinginan membangun took; 12) Keinginan membayar hutang; dan 13) Keinginan membeli atau menyawa sawah. Dari ketigabelas alasan ini kemudian dipersentasekan berdasarkan jawaban dari 42 orang responden. Setelah melakukan analisis data, diketahui bahwa tingkat motivasi buruh migran kembali ke negara tempat mereka bekerja berada pada kategori tinggi dengan persentase 78,16\%. Berdasarkan data tersebut jika diklasifikasikan ternyata tingginya motivasi buruh migran di Desa Senyiur kembali ke negara tempat mereka bekerja disebabkan oleh dua faktor, yaitu faktor kebutuhan konsumtif dan kebutuhan ekonomi produktif.

Berdasarkan hasil wawancara diketahui bahwa setelah buruh migran pergi merantau ke luar negeri dalam jangka waktu dua sampai tiga tahun, mereka biasanya akan pulang ke kampung halaman, yakni di Desa Senyiur Kecamatan Keruak. Tenggang waktu buruh migran berada di kampung halaman sejak kepulangannya dari negara tempat mereka bekerja diketahui hanya dalam waktu satu bulan saja. Setelah kurang lebih selama satu bulan di kampung halamn/di rumahnya, maka para buruh migran yang ada di Desa Senyiur akan berangkat kembali merantau menuju ngara di mana mereka bekerja sebelumnya. Selain alasan-alasan yang telah dikemukakan, tentu juga para buruh migran merasa khawatir akan kehilangan pekerjaan jika lama tidak kembali ke Negara tempat mereka bekerja, karena mereka takut digantikan dengan tenaga kerja yang baru. Selain itu terdapat pula buruh migran yang memang sudah dijadwalkan jumlah hari yang dapat digunakan untuk cuti bekerja. Hal inilah yang kemudian semakin menjadi pendorong bagi buruh migran kembali ke negara di mana mereka bekerja.

\section{Pemanfaatan remitan untuk kegiatan konsumtif}

Sebagaimana alasan yang menjadi penyebab buruh migran kembali ke Negara tempat mereka bekerja, remitan baik berupa uang maupun barang dimanfaatkan untuk dua kebutuhan, yaitu kebutuhan konsumtif dan ekonomi produktif. Berdasarkan jawaban atas angket yang diberikan, ternyata ada beberapa jenis pemanfaatan remitan yang dilakukan oleh buruh migran. Khususnya untuk kebutuhan konsumtif, antara lain: 1) untuk membayar hutang; 2) untuk membangun rumah; 3) membeli peralatan rumah tangga dan pakaian; 4) membeli kebutuhan sehari-hari; 5) membeli sepeda motor; dan 6) biaya 
pendidikan anak. Dari hasil analisis data diketahui bahwa pemanfaatan remitan oleh buruh migran untuk kegiatan konsumtif berada pada kategori tinggi dengan persentase 89,40\%.

Jika diuraikan satu persatu, maka kita akan menemukan pemanfaatan remitan untuk kegiatan konsumtif yang pertama kali adalah untuk membayar hutang dari keberangkatan para buruh migran. Berdasarkan jawaban responden sebanyak $88,09 \%$ menjawab setuju bahwa remitan yang dikirimkan digunakan untuk membayar hutang, khususnya hutang yang digunakan sebagai biaya keberangkatan ke luar negeri untuk bekerja. Kedua, pemanfaatan remitan oleh buruh migran digunakan untuk membangun rumah pribadi. Hal ini disebabkan karena sebagian besar dari buruh migran yang pergi merantau sebelumnya belum memiliki rumah pribadi dan masih menumpang di rumah orang tua mereka. Hasil jawaban responden menunjukkan 97,61\% menyatakan setuju bahwa remitan digunakan untuk membangun rumah pribadi. Dari kenyataan langsung juga setelah melakukan observasi di lapangan, keadaan tempat tinggal para buruh migran di Desa Senyiur dapat dikatakan rata-rata layak huni. Kelengkapan fasilitas rumah tangga yang dimilikinya juga sudah cukup tersedia. Seperti kepemilikan sepeda motor, TV, VCD, kulkas, mesin cuci, dan lain-lain. Bahan bangunan yang digunakan pun cukup berkualitas dan relatif kokoh, khususnya menggunakan batu bata dan semen, sebagaimana ditampilkan pada gambar 1. Namun demikian, bagi para buruh migran, proses pembangunan rumah membutuhkan biaya yang cukup besar yakni berkisar antara lima puluh sampai tujuh puluh juta rupiah. Rumah yang dibangun pun masih dalam keadaan setengah jadi. Sehingga kepergian para buruh migran kembali ke negara tempat mereka bekerja digunakan untuk menyelesaikan pembangunan rumah yang belum selesai.

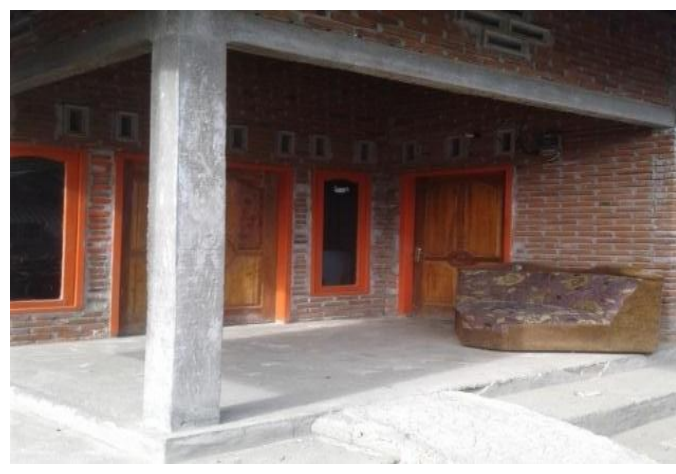

A

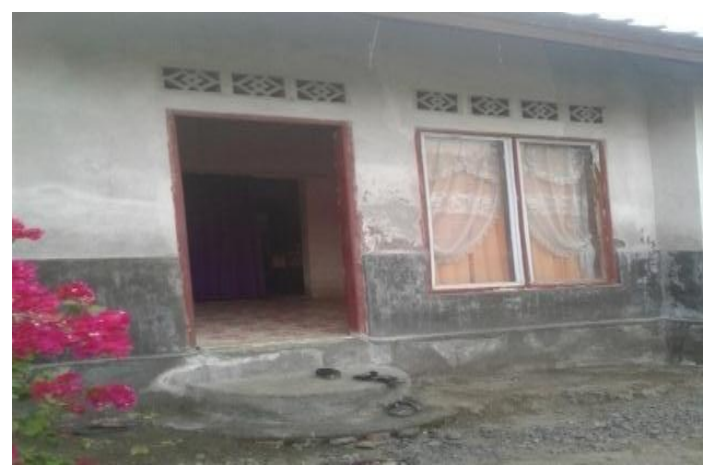

B

Gambar 1. Rumah pribadi milik buruh migran bernama Miftahuddin (A) dan Mayadi (B) sebagai pemanfaatan remitan untuk kegiatan konsumtif

(Sumber: Dokumen Peneliti, 2019)

Pemanfaatan remitan untuk kegiatan konsumtif selanjutnya adalah untuk membeli alat transportasi berupa sepeda motor. Hal ini disebabkan karena untuk kebutuhan transportasi sehari-hari pilihan sepeda motor adalah yang paling memungkinkan dan terjangkau. Kondisi ini mengingat desa Senyiur merupakan desa yang tidak dilalui oleh alat transportasi massa yang murah dan mudah diakses. Selain itu remitan yang terkirim juga dimanfaatkan untuk membeli peralatan rumah tangga dan pakaian. Hal yang paling utama, tentunya remitan digunakan untuk membeli kebutuhan sehari-hari. Khususnya untuk kebutuhan makan dan membeli kebutuhan lainnya. Terakhir pemanfaatan remitan untuk kebutuhan konsumtif digunakan untuk membiayai pendidikan anak. Hal ini penting tentunya bagi masa depan anak mereka. Melalui fakta ini menunjukkan bahwa para buruh migran sebagiannya sudah sadar akan pentingnya pendidikan anak sebagai investasi jangka panjang di masa yang akan datang.

Pemanfaatan remitan untuk kegiatan konsumtif yang tinggi menyebabkan remitan yang awal mulanya diniatkan untuk ekonomi produktif, belum dapat terealisasi. Pada akhirnya, belum tercapainya pemanfaatan remitan untuk kegiatan ekonomi produktif menyebabkan arus migran kembali terus menjadi tinggi. Dua jenis tujuan pemanfaatan remitan ini menjadi pendorong para buruh migran terus kembali ke Negara tempat mereka bekerja. Kemudian dalam jangka waktu dua sampai tiga tahun mereka akan pulang. Berselang sebulan mereka berangkat lagi ke Negara di mana mereka bekerja. 
Begitu seterusnya seperti siklus yang tidak berujung. Sampai mereka menemukan satu masa di mana mereka harus dipaksa berhenti mengikuti siklus tersebut.

\section{Pemanfaatan remitan untuk kegiatan ekonomi produktif}

Selain untuk tujuan kebutuhan konsumtif, juga diketahui juga beberapa buruh migran berhasil memanfaatkan remitan untuk kebutuhan atau kegiatan ekonomi produktif. Berdasarkan hasil jawaban responden pada angket yang telah diberikan beserta hasil observasi di lapangan maka diketahui bahwa pemanfaatan remitan untuk kegiatan ekonomi produktif digunakan untuk:1) membeli atau menyewa sawah; 2) modal usaha; 3) menabung; 4) modal usaha orang lain (sharing); dan 5) membeli hewan ternak. Setelah dilakukan analisis data berdasarkan jawaban seluruh responden, ditamukan hasil bahwa pemanfaatan remitan oleh buruh migran untuk kegiatan ekonomi produktif berada pada kategori rendah, dengan persentase 10,6\%. Penggunaan remitan untuk kegiatan ekonomi produktif utamanya digunakan untuk untuk membeli atau menyewa sawah. Berdasarkan hasil wawancara ditemukan bahwa terdapat beberapa buruh migran yang menggunakan remitan untuk membeli ataupun menyewa sawah. Sawah yang telah dibeli ataupun disewa tersebut kemudian dikelola agar mereka dapat memperoleh hasil berupa keuntungan usaha tani. Jumlah responden yang menjawab setuju remitan dimanfaatkan untuk membeli atau menyewa sawah relatif kecil, yaitu hanya 11,90\% dari keseluruhan responden.

Sementara itu sebagian buruh migran juga memanfaatkan remitan untuk kebutuhan menabung. Namun demikian, jumlah migran yang menggunakan remitan untuk menabung masih tergolong sedikit, yaitu 14,28\%. Pemanfaatan remitan untuk kegiatan ekonomi produktif yang selanjutnya adalah untuk membeli hewan ternak seperti sapi, kerbau dan lain-lain. Berdasarkan hasil jawaban responden diketahui responden yang setuju dengan pemanfaatan remitan untuk membeli ternak sebanyak $14,28 \%$. Selain itu remitan yang terkirim juga dimanfaatkan untuk modal usaha. Sebanyak 11,90\% responden menyatakan bahwa setuju pemanfaatan remitan sebagai modal usaha. Berdasarkan hasil observasi dan wawancara diketahui bahwa beberapa dari buruh migran tersebut memiliki usaha dagang kecil-kecilan di rumahnya. Terutama menjual kebutuhan sehari-hari seperti beras, gula, kopi, sabun, makanan ringan dan lainnya. Meskipun sebagian dari buruh migran memiliki kios sebagai tempat berjualan, beberapa buruh migran yang lain juga tetap berjualan meskipun tidak memiliki tempat khusus untuk berdagang, akan tetapi mereka memanfaatkan beberapa dari ruangan rumah mereka untuk berjualan.

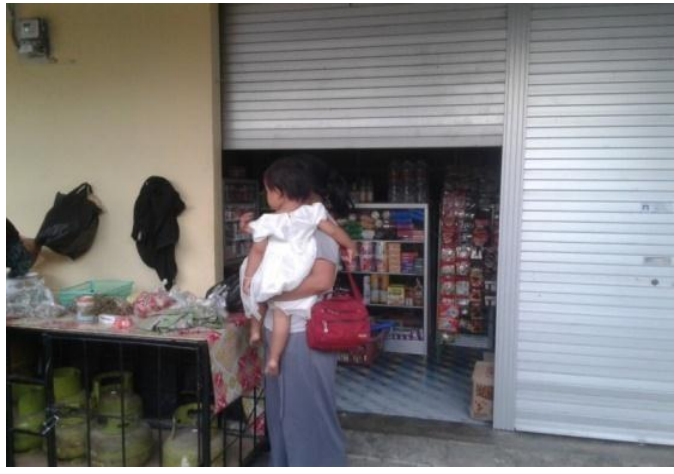

A

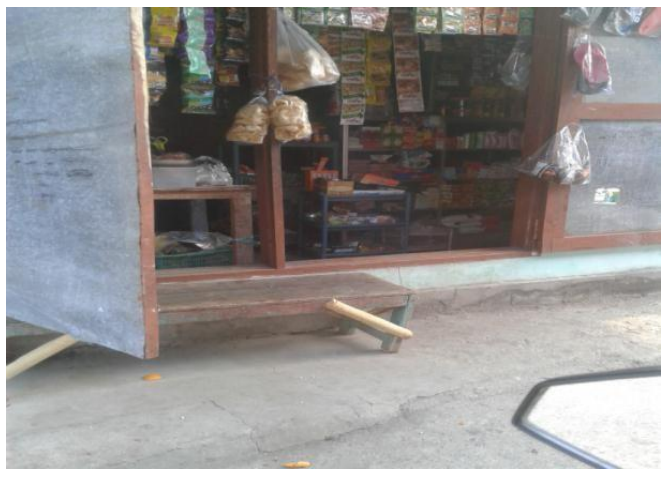

B

Gambar 2. Kios dari buruh migran bernama Marzoan (A) dan Salamuddin (B) yang memanfaatkan remitan untuk kegiatan ekonomi produktif yakni berdagang

(Sumber: Dokumen Peneliti, 2019)

Selain pemanfaatan remitan untuk membuka usaha sendiri berupa berdagang, sebagan dari buruh migran juga memanfaatkan remitan sebagai modal usaha bagi orang lain. Remitan yang terkirim dipinjamkan sebagai modal usaha orang lain. Namun demikian, jumlah buruh migran yang meminjamkan remitan sebagai modal usaha untuk orang lain relatif sangat sedikit. Untuk dapat memanfaatkan remitan ke dalam kegiatan ekonomi produktif, maka para buruh migran harus melakukan migrasi kembali paling sedikit tiga kali. Itu ungkapan dari salah seorang migran kembali 
ketika dilakukan wawancara secara langsung. Buruh migran ini berpendapat bahwa, jika seorang migran berniat untuk memanfaatkan remitan untuk kegiatan ekonomi produktif, maka dari awal harus memiliki niat dan tekat yang kuat. Hal lain yang perlu di ingat juga yaitu para buruh migran harus berhemat dan tidak boros dalam memakai uang kiriman atau remitan.

Selain kegiatan ekonomi produktif berupa usaha tani, berdagang kecil-kecilan dan meminjamkan remitan sebagai usaha orang lain dengan skema bagi hasil, ada pula buruh migran yang cukup lama bekerja dan mendapat remitan cukup besar melakukan aktivitas ekonomi produktif berupa membuka jasa angkutan dengan mobil pick up (bak terbuka). Usaha tersebut terutama untuk mengangkut barangbarang atau hasil pertanian seperti tembakau, padi, jagung dan hasil pertanian lainnya. Hasil berupa mobil bak terbuka ini diperoleh setelah melakukan migrasi kembali selama kurang lebih enam kali. Jika dilihat tahapannya keberangkatan pertama digunakan untuk membayar hutang biaya keberangkatan, keberangkatan ke dua dan ketiga digunakan untuk membangun rumah, keempat utuk biaya membeli sepeda motor dan menikah, kelima dan keenam serta seterusnya untuk kebutuhan ekonomi produktif yang membutuhkan biaya cukup besar seperti usaha angkutan barang tersebut.

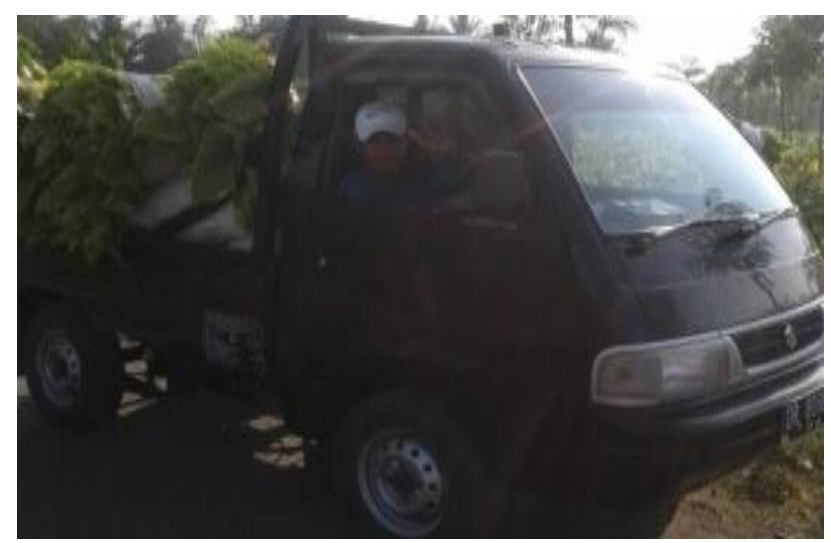

Gambar 3. Usaha jasa angkutan barang dengan mobil pick up milik seorang buruh migran bernama Hilman

(Sumber: Dokumen Peneliti, 2019)

Pemanfaatan remitan untuk kegiatan ekonomi produktif rata-rata dilakukan oleh buruh migran yang telah menikah dan berumah tangga. Sementara itu bagi buruh migran yang belum menikah, maka mereka cenderung tidak memanfaatkan remitan untuk kegiatan ekonomi produktif, namun lebih digunakan pada kebutuhan-kebutuhan konsumtif. Meskipun demikian, sebagian buruh migran yang belum menikah juga sudah mulai memikirkan masa depannya. Sehingga remitan yang dikirimkan digunakan untuk membangun rumah sebagai tempat ketika sudah melangsungkan pernikahan dan berumah tangga di kemudian hari.

Kondisi ekonomi keluarga buruh migran tergolong berada pada tingkat menengah ke bawah. Hal ini terlihat berdasarkan hasil observasi pada aktivitas sehari-hari yang dilakukan oleh keluarga para buruh migran. Rata-rata mereka selalu mencari pekerjaan secara serabutan untuk mendapatkan uang sehingga bisa membantu memenuhi kebutuhan sehari-hari. Salah satunya bekerja sebagai buruh tani dengan upah yang relatif kecil. Keseharian dari kehidupan sebagian keluarga buruh migran masih serba kekurangan atau bisa dikatakan jauh dari kata cukup. Kondisi ekonomi keluarga buruh migran itu dapat diukur dari terpenuhi atau tidaknya kebutuhan primer dan sekunder mereka. Terutama terpenuhinya kebutuhan primer khususnya kebutuhan sehari-sehari seperti kebutuhan makanan, minuman, baju dan tempat tinggal yang layak. Selain kondisi ekonomi sebagian keluarga buruh migran berada pada tingkat menengah ke bawah, kebutuhan konsumsi dari kelurga buruh migran juga relative tinggi. Jumlah biaya konsumsi yang dikeluarkan oleh keluarga akan bertambah besar apabila pada hari-hari tertentu seperti ketika ada acara syukuran keluarga dan peringatan hari-hari besar Islam. Seperti pada acara peringatan maulid nabi besar Muhammad Saw dan acara-acara peringatan hari besar Islam lainnya.

Kebiasaan konsumtif yang juga sering dilakukan keluarga buruh migran adalah melakukan rekreasi secara beramai-ramai ke tempat wisata pada hari-hari tertentu. Biasannya pada peringatan tahun baru masehi, pada awal bulan Ramadan dan pada hari raya Idul Fitri. Pada hari pertama masuknya 
tahun baru masehi para kelurga buruh migran biasanya bepergian atau dapat dikatakan melakukan rekreasi ke berbagai tempat. Tentu saja hal itu akan menambah pengeluaran atau biaya. Sedangkan pada bulan Ramadan biasanya biaya konsumsi akan bertambah terutama untuk membeli lauk-pauk dan menu berbuka puasa. Hal inilah yang menjadi penyebab mengapa kegiatan konsumtif masih mendominasi pemanfaatan remitan jika dibandingkan dengan aktivitas ekonomi produktif.

\section{SIMPULAN}

Berdasarkan hasil temuan dan pembahasan maka didapatkan kesimpulan penelitian sebagai berikut: 1) tingkat motivasi buruh migran untuk bekerja kembali ke luar negeri berada pada kategori tinggi dengan persentase $78,16 \%$. Alasan yang menjadi motivasi buruh migran kembali adalah keinginan mencukupi konsumsi (kebutuhan makan) keluarga; keinginan membiayai sekolah anak; keinginan meningkatkan status sosial; faktor lemahnya ekonomi keluarga; keinginan mengirim uang dan barang kepada keluarga; upah yang rendah di daerah asal; keinginan menggapai cita-cita; keinginan membangun rumah pribadi; keinginan untuk menabung; keinginan membangun toko; keinginan membayar hutang; dan keinginan membeli atau menyawa sawah untuk usaha tani. 2) pemanfaatan remitan untuk kegiatan konsumtif berada pada kategori tinggi dengan persentase $89,40 \%$. Jenis pemanfaatan remitan untuk kegiatan konsumtif seperti untuk membayar hutang; untuk membangun rumah; untuk membeli peralatan rumah tangga dan pakaian; untuk membeli kebutuhan sehari-hari; untuk membeli sepeda motor; dan biaya pendidikan anak. Sementara pemanfaatan untuk kegiatan ekonomi produktif berada pada kategori rendah dengan persentase 10,6\%. Adapun jenis pemanfaatan remitan untuk kegiatan ekonomi produktif antara lain membeli atau menyewa sawah; sebagai modal usaha; untuk menabung; sebagai modal usaha orang lain (sharing); dan untuk membeli hewan ternak.

\section{DAFTAR PUSTAKA}

Antaranews.com. (2015). 56.672 warga NTB memilih jadi TKI. Diakses tanggal 17 Maret 2019 dari https://www.antaranews.com/berita/474792/56672-warga-ntb-memilih-jadi-tki

Astuti, E. D., \& Giyarsih, S. R. (2013). Peran remitan TKI terhadap peningkatan kualitas permukiman di Desa Jangkaran Kecamatan Temon Kabupaten Kulonprogo (The role of remitances of Indonesian labor in the settlement quality increase in Jangkaran village, Temon sub district, Kulonprogo). Jurnal Manusia dan Lingkungan, 20(2), 184-189.

BPS (2018). Statistik Pendapatan Agustus 2018. Jakarta: Badan Pusat Statistik.

Hadi, H. (2016). Analisis deskriptif persentase pada penelitian survey. Makalah, tidak diterbitkan. Selong: Universitas Hamzanwadi.

Haris, A. (2005). Kucuran keringat dan derap pembangunan Jejak migran dalam pembangunan daerah).Yogyakarta: Pustaka Pelajar.

Irawaty, T., \& Wahyuni, E. S. (2011). Migrasi internasional perempuan desa dan pemanfaatan remitan di Desa Pusakajaya, Kecamatan Pusakajaya, Kabupaten Subang, Provinsi Jawa Barat. Sodality: Jurnal Transdisiplin Sosiologi, Komunikasi, dan Ekologi Manusia, 5(3), 297-310.

Mantra, I. B. (2011). Demografi Umum. Yogyakarta: Pustaka Pelajar.

Pangestu, F. W., \& Pitoyo, A. J. (2015). Pemanfaatan remitan tenaga kerja wanita untuk pendidikan anak di Desa Jangkaran, Kecamatan Temon, Kabupaten Kulon Progo. Jurnal Bumi Indonesia, 4(4), $1-9$.

Ridwan (2004). Belajar mudah penelitian untuk guru-karyawan dan peneliti pemula. Bandung: Alfabeta.

Sriwanto, S., \& Sarjanti, E. (2019). Optimalisasi pemanfaatan remitan untuk pemberdayaan lahan pertanian di Kecamatan Gumelar Kabupaten Banyumas. Proceeding of The URECOL, 258-266. 
Suarantb.com. (2018). 11.843 orang pekerja NTB berangkat ke luar negeri. Diakses tanggal 17 Maret 2019 dari https://www.antaranews.com/berita/474792/56672-warga-ntb-memilih-jadi-tki

Subianto, A. (2006). Pengarub pemanfaatan remitan burub migran terhadap pertumbuban ekonomi wilayah di Kabupaten Cilacap (Studi Kasus di Kecamatan Adipala, Kecamatan Binangun dan Kecamatan Nusawungu). Thesis, tidak diterbitkan. Semarang: Universitas Diponegoro.

Suroso. (2017). Profil sektor informal pada kawasan wisata pantai Labuhan Haji Kabupaten Lombok Timur. Geodika: Jurnal Kajian Ilmu dan Pendidikan Geografi. 1(1), 57-64.

Tjiptoherijanto, P. (1997). Migrasi, Urbanisasi dan Pasar Kerja di Indonesia. Jakarta: Penerbit Universitas Indonesia.

Yulkardi, A., Riyadi, B., Endang, S. (2000). Migrasi dan remitan suatu gerak komersial. Yogyakarta: Program Studi Kependudukan Universitas Gadjah Mada. 